\title{
Acetobacter fabarum sp. nov., an acetic acid bacterium from a Ghanaian cocoa bean heap fermentation
}

Correspondence

Ilse Cleenwerck

Ilse.Cleenwerck@ugent.be

\author{
Ilse Cleenwerck, ${ }^{1}$ Ángel Gonzalez, ${ }^{2}$ Nicholas Camu, ${ }^{2}$ Katrien Engelbeen, ${ }^{1}$ \\ Paul De Vos ${ }^{1,3}$ and Luc De Vuyst ${ }^{2}$
}

${ }^{1}$ BCCM/LMG Bacteria Collection, Faculty of Sciences, Ghent University, K. L. Ledeganckstraat 35, B-9000 Ghent, Belgium
${ }^{2}$ Research Group of Industrial Microbiology and Food Biotechnology, Department of Applied Biological Sciences and Engineering, Vrije Universiteit Brussel, Pleinlaan 2, B-1050 Brussels, Belgium
${ }^{3}$ Laboratory of Microbiology, Faculty of Sciences, Ghent University, K. L. Ledeganckstraat 35, B-9000 Ghent, Belgium

\begin{abstract}
Six acetic acid bacterial isolates, obtained during a study of the microbial diversity of spontaneous fermentations of Ghanaian cocoa beans, were subjected to a polyphasic taxonomic study. $(\mathrm{GTG})_{5}-\mathrm{PCR}$ fingerprinting grouped the isolates together, but they could not be identified using this method. Phylogenetic analysis based on 16S rRNA gene sequences allocated the isolates to the genus Acetobacter and revealed Acetobacter lovaniensis, Acetobacter ghanensis and Acetobacter syzygii to be nearest neighbours. DNA-DNA hybridizations demonstrated that the isolates belonged to a single novel genospecies that could be differentiated from its phylogenetically nearest neighbours by the following phenotypic characteristics: no production of 2-keto-D-gluconic acid from D-glucose; growth on methanol and D-xylose, but not on maltose, as sole carbon sources; no growth on yeast extract with $30 \% \mathrm{D}$-glucose; and weak growth at $37{ }^{\circ} \mathrm{C}$. The DNA G $+\mathrm{C}$ contents of four selected strains were $56.8-58.0 \mathrm{~mol} \%$. The results obtained prove that the isolates should be classified as representatives of a novel Acetobacter species, for which the name Acetobacter fabarum sp. nov. is proposed. The type strain is strain $985^{\top}\left(=\mathrm{R}-36330^{\top}=\right.$ LMG $\left.24244^{\top}=\mathrm{DSM} 19596^{\mathrm{T}}\right)$.
\end{abstract}

Acetic acid bacteria $(\mathrm{AAB})$ play an important role in cocoa bean fermentation (Schwan \& Wheals, 2004; Thompson et al., 2007). They oxidize ethanol, produced by yeasts, to acetic acid. This volatile acid, combined with the heat produced by the exothermic bioconversion, causes the death of the seed embryo and the end of the fermentation. The cocoa bean fermentation process leads to the formation of precursor molecules that are very important for development of the aroma, flavour and colour of the beans (Hansen et al., 1998; Thompson et al., 2007). Acetobacter and Gluconobacter species are most commonly found in cocoa bean fermentations (Ardhana \& Fleet, 2003;

Abbreviation: $A A B$, acetic acid bacteria.

The GenBank/EMBL/DDBJ accession numbers for the $16 \mathrm{~S}$ rRNA gene sequences of strains $985^{\top}$ and 1145 are AM905849 and AM905850, respectively.

A maximum-parsimony tree based on nearly complete $16 \mathrm{~S}$ rRNA gene sequences and additional differential characteristics of $A$. fabarum and phylogenetically related species are available as supplementary material with the online version of this paper.
Schwan \& Wheals, 2004; Lagunes Gálvez et al., 2007; Nielsen et al., 2007; Camu et al., 2007; De Vuyst et al., 2007). However, isolations of $\mathrm{AAB}$ from such fermentations have so far been performed on a very limited number of media, e.g. Nielsen et al. (2007) isolated AAB from glucose-yeast extract-calcium carbonate (GYC) agar (5\% D-glucose, $1 \%$ yeast extract, $3 \%$ calcium carbonate, $2 \%$ agar) (concentrations of all medium components are listed as w/v) and Camu et al. (2007) isolated them from deoxycholate-mannitolsorbitol (DMS) agar ( $1 \%$ peptone, $0.3 \%$ yeast extract, $1.5 \%$ calcium lactate, $0.1 \%$ D-glucose, $0.1 \%$ sorbitol, $0.1 \%$ Dmannitol, $0.1 \%$ potassium phosphate, $0.01 \%$ sodium deoxycholate, $0.002 \%$ magnesium sulphate, $0.003 \%$ bromocresol, $0.01 \%$ cycloheximide, $1.8 \%$ agar, $\mathrm{pH}$ 4.5; Guiraud, 1998). Several studies have pointed out that even minor modifications in the composition of the isolation medium can result in the isolation of representatives of so far unknown AAB taxa (Yamada et al., 2000; Lisdiyanti et al., 2001, 2003). For this reason, it has been suggested that a combination of media be used to avoid selective isolation of AAB (Lisdiyanti et al., 2003). 
During a study of the microbial biodiversity of spontaneous fermentations of Ghanaian cocoa beans, $209 \mathrm{AAB}$ isolates were collected from four different culture media: DMS agar (Guiraud, 1998); acetic acid medium (AAM) agar (1\% D-glucose, $0.5 \%$ ethanol, $0.3 \%$ acetic acid, $1.5 \%$ peptone, $0.8 \%$ yeast extract; Lisdiyanti et al., 2001); basal medium with ethanol (BME) agar [0.05\% yeast extract, $0.3 \%$ vitamin-free Casamino acids (Difco), $0.3 \%$ ethanol]; and glucose-yeast extract (GY) agar (5\% D-glucose, $0.5 \%$ yeast extract). The agar concentration in all media was $1.5 \%(\mathrm{w} / \mathrm{v})$. The isolates were investigated by $(\mathrm{GTG})_{5}-\mathrm{PCR}$ fingerprinting, a technique that has proven useful for rapid and reliable species identification and classification of lactobacilli (Gevers et al., 2001), enterococci (Švec et al., 2005) and AAB (De Vuyst et al., 2007; Cleenwerck et al., 2007). A group of six $A A B$ isolates that could not be identified was revealed (Fig. 1). The present study deals with the further characterization of these isolates and shows that they represent a novel species of the genus Acetobacter.

The six $\mathrm{AAB}$ isolates were collected from three of the four different culture media mentioned above: four isolates from AAM agar (isolates 900, 1145, 950 and 1104), one from BME agar (isolate $985^{\mathrm{T}}$ ) and one from GY agar (isolate 1039). No isolates were obtained from DMS medium, the medium that was used by Camu et al. (2007) to investigate AAB involved in cocoa fermentations. This observation confirms the importance of the use of a combination of media (Lisdiyanti et al., 2003) to avoid selective isolation of $\mathrm{AAB}$. The isolates were preserved as described previously (Cleenwerck et al., 2007) and recovered on MYP agar [2.5\% D-mannitol, $0.5 \%$ yeast extract, $0.3 \%$ bacteriological peptone, $1.5 \%$ agar (Oxoid); $\mathrm{w} / \mathrm{v}$ ] and $\mathrm{Z1}$ agar (2\% yeast extract, $2 \%$ calcium lactate, $1.5 \%$ agar; w/v) by incubation at $28{ }^{\circ} \mathrm{C}$ under aerobic conditions for 1-4 days. Isolates $985^{\mathrm{T}}, 1145,950$ and 1039 were deposited in the Research Collection of the Laboratory of Microbiology as R-36330 ${ }^{\mathrm{T}}$, R-36331, R36458 and R-36459, respectively. The type strains of the Acetobacter species used in this study were obtained from the BCCM/LMG Bacteria Collection (http://www.belspo. be/bccm/). They were grown according to the provider's specifications.

For microscopy, the isolates were grown on Z1 agar. Cells were tested for their Gram reaction, cell shape and size and catalase and oxidase activities according to methods described previously (Cleenwerck et al., 2002). After incubation at $28{ }^{\circ} \mathrm{C}$ for 3 days, the isolates appeared as rough, shiny, beige, round colonies that were raised and wavy, with a diameter of approximately $0.8 \mathrm{~mm}$. Cells of all isolates were motile, Gram-negative, coccoid rods $(0.8 \times 1.2-3.0 \mu \mathrm{m})$ that occurred singly or in pairs and were oxidase-negative and catalase-positive.

Sequences of the $16 \mathrm{~S}$ rRNA genes of isolates $985^{\mathrm{T}}$ and 1145 were determined following the protocol described by Franz et al. (2006) with the modification that DNA for sequencing was extracted by the method of Wilson (1987) as applied by Cleenwerck et al. (2002). Nearly complete 16S rRNA gene sequences were obtained using the primers ${ }^{\star} \mathrm{Gamma},{ }^{\star} \mathrm{PD},{ }^{\star} \mathrm{O},{ }^{\star} 3,{ }^{\star} \mathrm{R}, \mathrm{Gamma}, 3$ and BKL1 (Coenye et al., 1999; Cleenwerck et al., 2007). Pairwise similarities between the consensus sequences and $16 \mathrm{~S}$ rRNA gene sequences from the EMBL database were calculated with the BioNumerics 4.5 software package (Applied Maths) using an open gap penalty of $100 \%$ and a unit gap penalty of $0 \%$. Phylogenetic trees were constructed with the BioNumerics 4.5 software package using the neighbour-joining (Saitou \& Nei, 1987) and maximum-parsimony (Felsenstein, 1985) methods. The statistical reliability of the topology of the trees was evaluated by bootstrap analysis (Felsenstein, 1985). 16S rRNA gene sequence analysis revealed that the isolates were affiliated to the genus Acetobacter and, more precisely, in the sublineage (Lisdiyanti et al., 2001; Cleenwerck et al., 2002, 2007; Dutta \& Gachhui, 2006) containing Acetobacter lovaniensis, A. ghanensis, A. syzygii, A. peroxydans, A. pasteurianus and A. pomorum (Fig. 2 and Supplementary Fig. S1, available in IJSEM Online). Furthermore, the $16 \mathrm{~S}$ rRNA gene sequence similarities obtained by pairwise alignment showed that
요

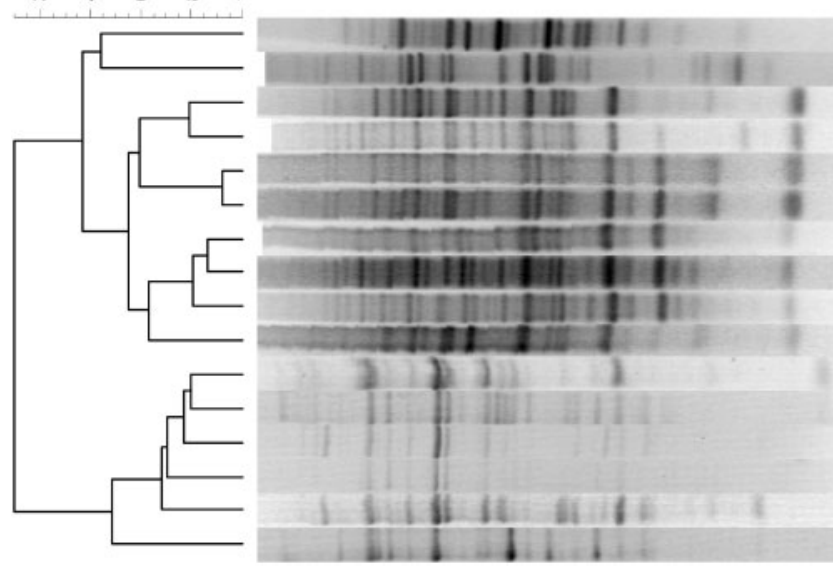

A. lovaniensis LMG $1617^{\top}$

A. syzygii LMG $21419 \mathrm{~T}$

A. ghanensis 440

A. ghanensis $112 \mathrm{~A}$

A. ghanensis $430 \mathrm{~A}^{\top}$

A. ghanensis 387A

A. ghanensis 384

A. ghanensis $153 \mathrm{~A}$

A. ghanensis 131

A. ghanensis 421

A. fabarum 985

A. fabarum 900

A. fabarum 1145

A. fabarum 950

A. fabarum 1039

A. fabarum 1104
Fig. 1. (GTG $)_{5}-P C R$ fingerprints of the six isolates of Acetobacter fabarum sp. nov. and their closest phylogenetic relatives. The dendrogram was derived from unweighted pairgroup cluster analysis (UPGMA) of the fingerprints. Levels of linkage are expressed as Pearson similarity coefficients. 


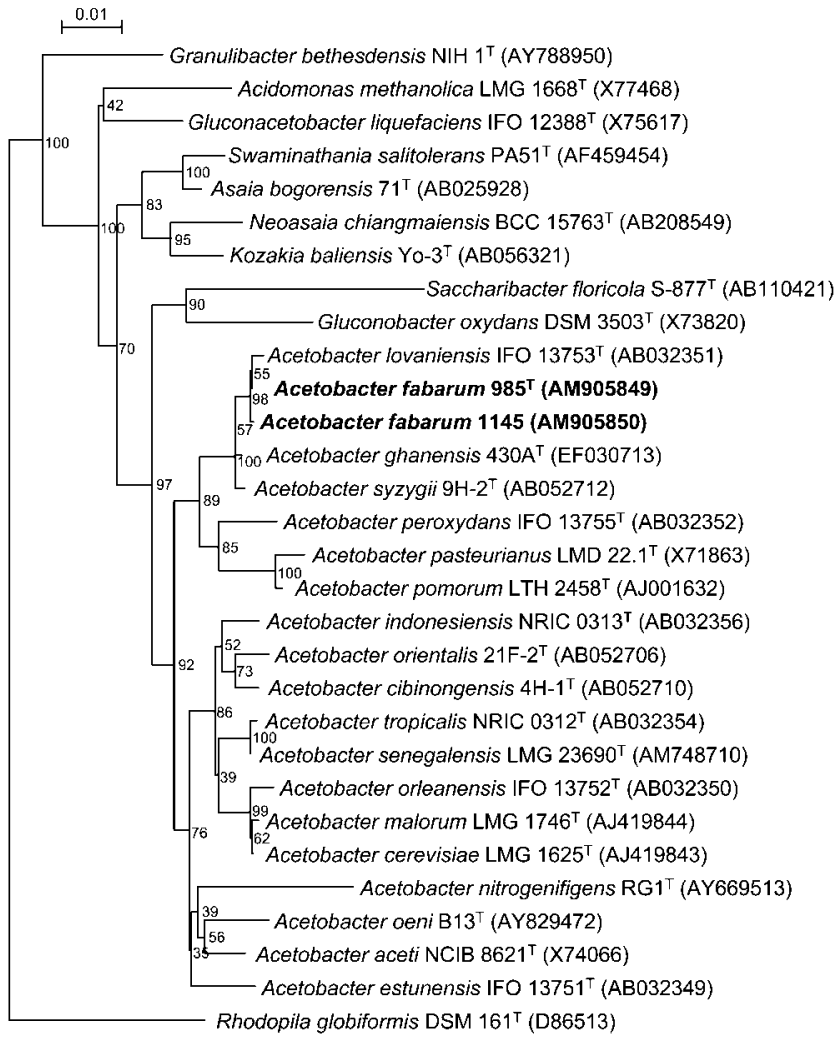

Fig. 2. Neighbour-joining tree based on nearly complete $16 \mathrm{~S}$ rRNA gene sequences of strains of $A$. fabarum sp. nov. and related species of the family Acetobacteraceae. The robustness of the branching is indicated by bootstrap percentages calculated for 1000 subsets. Bar, 1 substitution per 100 nucleotide positions.

isolates $985^{\mathrm{T}}$ and 1145 were closely related to each other ( $99.9 \%$ similarity) and to the type strains of A. lovaniensis (99.9\%), A. ghanensis (99.7\%) and A. syzygii (99.5\%). The isolates were clearly less related to the type strains of other recognized Acetobacter species: i.e. A. peroxydans and A. pomorum (97.9\%), A. senegalensis (97.6\%), A. orientalis, A. cibinongensis, A. tropicalis and A. indonesiensis (97.5\%), A. pasteurianus and A. aceti (97.4\%), A. estunensis and A. oeni (97.1\%), A. cerevisiae and A. malorum (97.0\%), A. orleanensis (96.9\%) and A. nitrogenifigens (96.6\%).

DNA-DNA hybridizations were performed between isolate $985^{\mathrm{T}}$ and the type strains of the phylogenetically related species A. lovaniensis, A. ghanensis, A. syzygii, A. peroxydans, A. pomorum and A. pasteurianus, and also between isolates $985^{\mathrm{T}}, 1145,950$ and 1039. DNA for DNA-DNA hybridizations and DNA base composition analysis was prepared by the method of Wilson (1987) with minor modifications (Cleenwerck et al., 2002). Only highmolecular-mass DNA with $A_{260} / A_{280}$ and $A_{234} / A_{260}$ ratios of $1.8-2.0$ and $0.40-0.60$, respectively, was used. DNADNA hybridizations were performed according to a modification (Goris et al., 1998; Cleenwerck et al., 2002) of the microplate method described by Ezaki et al. (1989).
The hybridization temperature was $46{ }^{\circ} \mathrm{C}$ in the presence of $50 \%$ formamide. Reciprocal reactions (e.g. $\mathrm{A} \times \mathrm{B}$ and $\mathrm{B} \times \mathrm{A}$ ) were performed for every DNA pair and their variation was within the limits of this method (Goris et al., 1998). The level of DNA-DNA binding found between isolate $985^{\mathrm{T}}$ and the type strains of phylogenetically related species was intermediate (52\% with A. lovaniensis LMG $1617^{\mathrm{T}}, 35 \%$ with $A$. ghanensis $\mathrm{R}-29337^{\mathrm{T}}$ and $32 \%$ with $A$. syzygii LMG $21419^{\mathrm{T}}$ ) or low (18\% with $A$. peroxydans LMG $1635^{\mathrm{T}}, 18 \%$ with $A$. pomorum LMG $18848^{\mathrm{T}}$ and $20 \%$ with A. pasteurianus LMG $1262^{\mathrm{T}}$ ). The level of DNA-DNA binding between isolates $985^{\mathrm{T}}, 1145,950$ and 1039 varied between 82 and $97 \%$. The DNA-DNA hybridization data demonstrate that the cocoa isolates represent a novel genospecies within the genus Acetobacter (Wayne et al., 1987; Stackebrandt et al., 2002). The DNA G + C contents of isolates $985^{\mathrm{T}}, 1145,950$ and 1039 were determined by HPLC according to the method of Mesbah et al. (1989). Non-methylated phage lambda DNA (Sigma) was used as calibration reference. The DNA G $+\mathrm{C}$ contents of isolates $985^{\mathrm{T}}, 1145,950$ and 1039 were $56.8-58.0 \mathrm{~mol} \%$, which is consistent with those of members of the genus Acetobacter (Lisdiyanti et al., 2000, 2001; Silva et al., 2006; Ndoye et al., 2007; Cleenwerck et al., 2007).

The production of gluconic acid, 2-keto-D-gluconic acid and 5-keto-D-gluconic acid from D-glucose was determined for isolates $985^{\mathrm{T}}, 1145,950$ and 1039 by the method described by Gosselé et al. (1980) using high-pressure anion-exchange chromatography with conductivity detection (Van der Meulen et al., 2006) instead of TLC. Physiological characteristics of isolates $985^{\mathrm{T}}, 1145,950$ and 1039 that enable differentiation from recognized Acetobacter species were examined by methods reported previously (Cleenwerck et al., 2002, 2007). Additionally, the isolates and strains of A. lovaniensis, A. ghanensis and A. syzygii, their phylogenetically nearest relatives, were examined for other physiological characteristics such as growth at different temperatures $\left(28,34,37\right.$ and $\left.42{ }^{\circ} \mathrm{C}\right)$ on GY agar (5\% D-glucose, $1 \%$ yeast extract, $1.5 \%$ agar) and growth on the carbon sources D-xylose, D-fructose, Dgalactose and D-glucose. The isolates could be differentiated from A. lovaniensis, A. ghanensis and A. syzygii by their inability to produce 2-keto-D-gluconic acid from Dglucose (differentiation from $A$. lovaniensis), their ability to grow on methanol (differentiation from $A$. ghanensis and A. syzygii) and D-xylose (differentiation from A. lovaniensis) but not on maltose as carbon sources (differentiation from A. syzygii), their inability to grow on yeast extract with $30 \%$ D-glucose (differentiation from A. ghanensis) and their weak growth at $37{ }^{\circ} \mathrm{C}$ (differentiation from $A$. lovaniensis, A. ghanensis and A. syzygii) (Table 1 and Supplementary Table S1).

In conclusion, the six isolates originating from Ghanaian cocoa bean fermentations constitute a taxon that can be differentiated genotypically and phenotypically from the 18 currently recognized Acetobacter species and should therefore be classified as representatives of a novel species, 


\section{Table 1. Differential characteristics of Acetobacter fabarum sp. nov. and recognized Acetobacter species}

Strains: 1, A. fabarum sp. nov. (4 strains); 2, A. lovaniensis LMG $1617^{\mathrm{T}}$; 3, A. ghanensis (3 strains); 4, A. syzygii LMG 21419 ${ }^{\mathrm{T}}$; 5, A. pasteurianus (7 strains); 6, A. pomorum LMG 18848 ${ }^{\mathrm{T}}$; 7, A. peroxydans (2 strains); 8, A. indonesiensis (2 strains); 9, A. orientalis LMG $21417^{\mathrm{T}} ; 10$, A. cibinongensis LMG $21418^{\mathrm{T}} ; 11$, A. tropicalis (2 strains); 12 , A. senegalensis (3 strains); 13 , A. orleanensis (4 strains); 14, A. malorum LMG $1746^{\mathrm{T}}$; 15, A. cerevisiae (4 strains); 16, A. nitrogenifigens $\mathrm{RGl}^{\mathrm{T}}$; 17, A. oeni $\mathrm{B} 13^{\mathrm{T}}$; 18, A. aceti (4 strains); 19, A. estunensis (3 strains). +, Positive; -, negative; $\mathrm{W}$, weakly positive; $\mathrm{V}$, variable (the result of the type strain of $A$. fabarum is given in parentheses). Except where indicated, data were taken from the following sources: column 1, this study; 2, 5-8, 11, 13-15 and 18-19, Cleenwerck et al. (2002); 3, Cleenwerck et al. (2007); 4, 9, 10 and 17, Silva et al. (2006); 12, Ndoye et al. (2007) (A. senegalensis CWBI-B418 ${ }^{\mathrm{T}}$ ) and Camu et al. (2007) (A. senegalensis 108B and 420A); 16, Dutta \& Gachhui (2006). Phenotypic characteristics taken from Cleenwerck et al. (2002, 2007), Silva et al. (2006), Ndoye et al. (2007) and Camu et al. (2007) were examined as described by Cleenwerck et al. (2002). YE, Yeast extract.

\begin{tabular}{|c|c|c|c|c|c|c|c|c|c|c|c|c|c|c|c|c|c|c|c|}
\hline Characteristic & 1 & 2 & 3 & 4 & 5 & 6 & 7 & 8 & 9 & 10 & 11 & 12 & 13 & 14 & 15 & 16 & 17 & 18 & 19 \\
\hline \multicolumn{20}{|l|}{ Formation from D-glucose of: } \\
\hline 5-Keto-D-gluconic acid & - & - & - & - & - & - & - & - & - & - & - & - & - & - & - & $\mathrm{ND}$ & + & + & - \\
\hline 2-Keto-D-gluconic acid & - & + & - & - & $\mathrm{v}$ & - & - & + & + & + & + & + & + & + & + & $\mathrm{ND}$ & - & + & + \\
\hline Growth in ammonium with ethanol & $\mathrm{v}(+)$ & + & - & - & - & - & + & - & - & $\mathrm{W}$ & - & + & - & - & - & + & - & + & + \\
\hline \multicolumn{20}{|l|}{ Growth on carbon sources } \\
\hline Glycerol & + & + & $\mathrm{w}$ & + & $\mathrm{V}$ & + & - & + & + & + & + & + & + & + & + & + & + & + & $\mathrm{V}$ \\
\hline Maltose & - & - & - & + & $\mathrm{v}$ & - & + & + & $\mathrm{w}$ & - & + & - & $\mathrm{V}$ & - & - & + & - & $\mathrm{V}$ & - \\
\hline Methanol & + & + & - & - & - & - & - & - & $\mathrm{w}$ & - & - & - & - & + & - & - & - & - & - \\
\hline Growth in $10 \%$ ethanol & $\mathrm{v}(-)$ & $-{ }^{a *}$ & $\mathrm{~V}$ & $-{ }^{a}$ & $+{ }^{a}$ & $-{ }^{a}$ & $-{ }^{a}$ & $-{ }^{a}$ & $-{ }^{a}$ & $-{ }^{a}$ & $-{ }^{a}$ & + & $-{ }^{a}$ & $+{ }^{b}$ & ND & + & + & $-{ }^{a}$ & $-{ }^{a}$ \\
\hline Growth on YE $+30 \%$ D-glucose & - & - & + & - & $\mathrm{V}$ & - & - & - & - & + & - & + & - & + & - & + & - & - & - \\
\hline Catalase & + & + & + & + & + & + & - & + & + & + & + & + & + & + & + & + & + & + & + \\
\hline DNA $G+C$ content $(\mathrm{mol} \%)$ & $\begin{array}{r}56.8- \\
58.0\end{array}$ & $\begin{array}{r}57.1- \\
58.9\end{array}$ & $\begin{array}{r}56.9- \\
57.3\end{array}$ & $\begin{array}{c}54.3- \\
55.4 \dagger\end{array}$ & $\begin{array}{r}53.2- \\
54.3\end{array}$ & 52.1 & $\begin{array}{r}59.7- \\
60.7\end{array}$ & $\begin{array}{r}54.0- \\
54.2\end{array}$ & $\begin{array}{c}52.0- \\
52.8^{\dagger}\end{array}$ & $\begin{array}{c}53.8- \\
54.5 \dagger\end{array}$ & $\begin{array}{r}55.6- \\
56.2\end{array}$ & $\begin{array}{r}55.6- \\
56.0\end{array}$ & $\begin{array}{c}55.7- \\
58.1\end{array}$ & 57.2 & $\begin{array}{r}56.0- \\
57.6\end{array}$ & 64.1 & 58.1 & $\begin{array}{r}56.9- \\
58.3\end{array}$ & $\begin{array}{r}59.2- \\
60.2\end{array}$ \\
\hline
\end{tabular}

${ }^{*}$ Data taken from: $a$, Lisdiyanti et al. (2001); $b$, Ndoye et al. (2007).

$\dagger$ Data were taken from Lisdiyanti et al. (2001) and are ranges for four (A. syzygii), nine (A. orientalis) and two (A. cibinongensis) strains, including the type strains. 
for which the name Acetobacter fabarum sp. nov. is proposed.

\section{Description of Acetobacter fabarum sp. nov.}

Acetobacter fabarum (fa.ba'rum. L. gen. pl. n. fabarum of beans, referring to the initial isolation of this species from cocoa beans).

Cells are Gram-negative, motile, coccoid rods, approximately $0.8 \mu \mathrm{m}$ wide and $1.2-3.0 \mu \mathrm{m}$ long. Cells occur singly or in pairs. Oxidase-negative. Catalase-positive. On Z1 agar, colonies are beige, round, raised, wavy, rough, shiny and approximately $0.8 \mathrm{~mm}$ in diameter after incubation at $28{ }^{\circ} \mathrm{C}$ for 3 days. Ethanol is oxidized to acetic acid. Gluconic acid is produced from D-glucose. Unable to produce 2-keto-Dgluconic acid or 5-keto-D-gluconic acid from D-glucose. Able to grow on methanol and D-xylose but not on maltose as sole carbon source. Unable to grow on yeast extract with $30 \%$ D-glucose. Growth with ammonium as sole nitrogen source and on glycerol and $10 \%$ ethanol as carbon source is variable between strains. The DNA $\mathrm{G}+\mathrm{C}$ content varies from 56.8 to $58.0 \mathrm{~mol} \%$. Can be differentiated genotypically from other Acetobacter species by DNA-DNA hybridization and $(\mathrm{GTG})_{5}-\mathrm{PCR}$ fingerprinting.

The type strain is strain $985^{\mathrm{T}}\left(=\mathrm{R}-36330^{\mathrm{T}}=\mathrm{LMG} 24244^{\mathrm{T}}\right.$ $=$ DSM $19596^{\mathrm{T}}$ ), isolated from a Ghanaian cocoa bean heap fermentation. The DNA G $+\mathrm{C}$ content of strain $985^{\mathrm{T}}$ is $57.6 \mathrm{~mol} \%$.

\section{Acknowledgements}

This research was funded by the Research Council of the Vrije Universiteit Brussel (OZR, GOA and IOF projects), the Fund for Scientific Research - Flanders, the Institute for the Promotion of Innovation through Science and Technology in Flanders (IWT Project 040043), the Federal Research Policy (Action for the promotion of and co-operation with the Belgian Coordinated Collections of Microorganisms, BCCM) and Barry Callebaut NV. The cooperation of the Ghanaian Cocoa Producers' Alliance (COCOBOD, Accra, Ghana) and the Cocoa Research Institute of Ghana is highly appreciated. Approval was obtained by the COCOBOD to cooperate with local farmers. The authors wish to acknowledge Katrien Vandemeulebroecke and Leentje Christiaens for determining 16S rRNA gene sequences, as well as Ann Van Schoor and Tom De Winter for their technical support.

\section{References}

Ardhana, M. M. \& Fleet, G. H. (2003). The microbial ecology of cocoa bean fermentations in Indonesia. Int J Food Microbiol 86, 87-99.

Camu, N., De Winter, T., Verbrugghe, K., Cleenwerck, I., Vandamme, P., Takrama, J. S., Vancanneyt, M. \& De Vuyst, L. (2007). Dynamics and biodiversity of populations of lactic acid bacteria and acetic acid bacteria involved in spontaneous heap fermentation of cocoa beans in Ghana. Appl Environ Microbiol 73, 1809-1824.

Cleenwerck, I., Vandemeulebroecke, K., Janssens, D. \& Swings, J. (2002). Re-examination of the genus Acetobacter, with descriptions of Acetobacter cerevisiae sp. nov. and Acetobacter malorum sp. nov. Int $J$ Syst Evol Microbiol 52, 1551-1558.
Cleenwerck, I., Camu, N., Engelbeen, K., De Winter, T., Vandemeulebroecke, K., De Vos, P. \& De Vuyst, L. (2007). Acetobacter ghanensis sp. nov., a novel acetic acid bacterium isolated from traditional heap fermentations of Ghanaian cocoa beans. Int $J$ Syst Evol Microbiol 57, 1647-1652.

Coenye, T., Falsen, E., Vancanneyt, M., Hoste, B., Govan, J. R. W., Kersters, K. \& Vandamme, P. (1999). Classification of Alcaligenes faecalis-like isolates from the environment and human clinical samples as Ralstonia gilardii sp. nov. Int J Syst Bacteriol 49, 405-413.

De Vuyst, L., Camu, N., De Winter, T., Vandemeulebroecke, K., Van de Perre, V., Vancanneyt, M., De Vos, P. \& Cleenwerck, I. (2008). Validation of the $(\mathrm{GTG})_{5}$-rep-PCR fingerprinting technique for rapid classification and identification of acetic acid bacteria, with a focus on isolates from Ghanaian fermented cocoa beans. Int J Food Microbiol 125, 79-90.

Dutta, D. \& Gachhui, R. (2006). Novel nitrogen-fixing Acetobacter nitrogenifigens sp. nov., isolated from Kombucha tea. Int J Syst Evol Microbiol 56, 1899-1903.

Ezaki, T., Hashimoto, Y. \& Yabuuchi, E. (1989). Fluorometric deoxyribonucleic acid-deoxyribonucleic acid hybridization in microdilution wells as an alternative to membrane filter hybridization in which radioisotopes are used to determine genetic relatedness among bacterial strains. Int J Syst Bacteriol 39, 224-229.

Felsenstein, J. (1985). Confidence limits on phylogenies: an approach using the bootstrap. Evolution 39, 783-791.

Franz, C. M. A. P., Vancanneyt, M., Vandemeulebroecke, K., De Wachter, M., Cleenwerck, I., Hoste, B., Schillinger, U., Holzapfel, W. H. \& Swings, J. (2006). Pediococcus stilesii sp. nov., isolated from maize grains. Int J Syst Evol Microbiol 56, 329-333.

Gevers, D., Huys, G. \& Swings, J. (2001). Applicability of rep-PCR fingerprinting for differentiation of Lactobacillus species. FEMS Microbiol Lett 205, 31-36.

Goris, J., Suzuki, K., De Vos, P., Nakase, T. \& Kersters, K. (1998). Evaluation of a microplate DNA-DNA hybridization method compared with the initial renaturation method. Can J Microbiol 44, 1148-1153.

Gosselé, F., Swings, J. \& De Ley, J. (1980). A rapid, simple and simultaneous detection of 2-keto, 5-keto- and 2,5-diketogluconic acids by thin-layer chromatography in culture media of acetic acid bacteria. Zentralbl Bakteriol Parasitenkd Infektionskr Hyg Abt I Orig C1, 178-181.

Guiraud, J.-P. (1998). Microbiologie Alimentaire. Paris: Dunod (in French).

Hansen, C. E., del Olmo, M. \& Burri, C. (1998). Enzyme activities in cocoa beans during fermentation. J Sci Food Agric 77, 273-281.

Lagunes Gálvez, S., Loiseau, G., Paredes, J. L., Barel, M. \& Guiraud, J.-P. (2007). Study on the microflora and biochemistry of cocoa fermentation in the Dominican Republic. Int J Food Microbiol 114, $124-130$

Lisdiyanti, P., Kawasaki, H., Seki, T., Yamada, Y., Uchimura, T. \& Komagata, K. (2000). Systematic study of the genus Acetobacter with descriptions of Acetobacter indonesiensis sp. nov., Acetobacter tropicalis sp. nov., Acetobacter orleanensis (Henneberg 1906) comb. nov., Acetobacter lovaniensis (Frateur 1950) comb. nov., and Acetobacter estunensis (Carr 1958) comb. nov. J Gen Appl Microbiol 46, 147-165.

Lisdiyanti, P., Kawasaki, H., Seki, T., Yamada, Y., Uchimura, T. \& Komagata, K. (2001). Identification of Acetobacter strains isolated from Indonesian sources, and proposals of Acetobacter syzygii sp. nov., Acetobacter cibinongensis sp. nov., and Acetobacter orientalis sp. nov. J Gen Appl Microbiol 47, 119-131.

Lisdiyanti, P., Katsura, K., Potacharoen, W., Navarro, R. R., Yamada, Y., Uchimura, T. \& Komagata, K. (2003). Diversity of acetic acid bacteria 
in Indonesia, Thailand, and the Philippines. Microbiol Cult Collect 19, 91-99.

Mesbah, M., Premachandran, U. \& Whitman, W. B. (1989). Precise measurement of the $\mathrm{G}+\mathrm{C}$ content of deoxyribonucleic acid by highperformance liquid chromatography. Int J Syst Bacteriol 39, 159-167.

Ndoye, B., Cleenwerck, I., Engelbeen, K., Dubois-Dauphin, R., Guiro, A. T., Van Trappen, S., Willems, A. \& Thonart, P. (2007). Acetobacter senegalensis sp. nov., a thermotolerant acetic acid bacterium isolated in Senegal (sub-Saharan Africa) from mango fruit (Mangifera indica L.). Int J Syst Evol Microbiol 57, 1576-1581.

Nielsen, D. S., Teniola, O. D., Ban-Koffi, L., Owusu, M., Andersson, T. S. \& Holzapfel, W. H. (2007). The microbiology of Ghanaian cocoa fermentations analysed using culture-dependent and culture-independent methods. Int J Food Microbiol 114, 168-186.

Saitou, N. \& Nei, M. (1987). The neighbor-joining method: a new method for reconstructing phylogenetic trees. Mol Biol Evol 4 , 406-425.

Schwan, R. F. \& Wheals, A. E. (2004). The microbiology of cocoa fermentation and its role in chocolate quality. Crit Rev Food Sci Nutr 44, 205-221.

Silva, L. R., Cleenwerck, I., Rivas, R., Swings, J., Trujillo, M. E., Willems, A. \& Velázquez, E. (2006). Acetobacter oeni sp. nov., isolated from spoiled red wine. Int J Syst Evol Microbiol 56, 21-24.

Stackebrandt, E., Frederiksen, W., Garrity, G. M., Grimont, P. A. D., Kämpfer, P., Maiden, M. C. J., Nesme, X., Rosselló-Mora, R., Swings, J. \& other authors (2002). Report of the ad hoc committee for the re-evaluation of the species definition in bacteriology. Int J Syst Evol Microbiol 52, 1043-1047.

Švec, P., Vancanneyt, M., Seman, M., Snauwaert, C., Lefebvre, K., Sedláček, I. \& Swings, J. (2005). Evaluation of (GTG) ${ }_{5}-\mathrm{PCR}$ for identification of Enterococcus spp. FEMS Microbiol Lett 247, 59-63.

Thompson, S. S., Miller, K. B. \& Lopez, A. S. (2007). Cocoa and coffee. In Food Microbiology: Fundamentals and Frontiers, 3rd edn, pp. 837-849. Edited by M. P. Doyle, L. R. Beuchat \& T. J. Montville. Washington, DC: American Society for Microbiology.

Van der Meulen, R., Adriany, T., Verbrugghe, K. \& De Vuyst, L. (2006). Kinetic analysis of bifidobacterial metabolism reveals a minor role for succinic acid in the regeneration of NAD + through its growth-associated production. Appl Environ Microbiol 72, 5204-5210.

Wayne, L. G., Brenner, D. J., Colwell, R. R., Grimont, P. A. D., Kandler, O., Krichevsky, M. I., Moore, L. H., Moore, W. E. C., Murray, R. G. E. \& other authors (1987). International Committee on Systematic Bacteriology. Report of the ad hoc committee on reconciliation of approaches to bacterial systematics. Int J Syst Bacteriol 37, 463-464.

Wilson, K. (1987). Preparation of genomic DNA from bacteria. In Current Protocols in Molecular Biology, pp. 2.4.1.-2.4.5. Edited by F. M. Ausubel, R. Brent, R. E. Kingston, D. D. Moore, J. G. Seidman, J. A. Smith \& K. Struhl. New York: Green Publishing \& Wiley-Interscience.

Yamada, Y., Katsura, K., Kawasaki, H., Widyastuti, Y., Saono, S., Seki, T., Uchimura, T. \& Komagata, K. (2000). Asaia bogorensis gen. nov., sp. nov., an unusual acetic acid bacterium in the $\alpha$ Proteobacteria. Int J Syst Evol Microbiol 50, 823-829. 